\title{
New species of miniature fish from Marajó Island, Pará, Brazil, with comments on its relationships (Characiformes: Characidae)
}

\author{
Manoela M. F. Marinhoํㅡㄹ Douglas A. Bastos² and Naércio A. Menezes ${ }^{1}$
}

A new miniature species of the family Characidae from Marajó Island, Pará State, Brazil is described and assigned to the genus Tyttobrycon. The new species can be distinguished from its congeners primarily by having multicuspid teeth on jaws, and additionally by having the combination of 5-7 premaxillary teeth, dorsal fin only with scattered melanophores and the presence of an adipose fin.

Uma espécie nova miniatura da família Characidae da Ilha do Marajó, Pará, Brasil, é descrita e atribuída ao gênero Tyttobrycon. A espécie nova pode ser diferenciada dos congêneres principalmente por ter dentes multicuspidados nas maxilas e adicionalmente por ter a combinação de 5-7 dentes no pré maxilar, nadadeira dorsal apenas com pequenos cromatóforos escuros dispersos e presença de nadadeira adiposa.

Key words: Aphyoditeinae, Neotropical, Sexual dimorphism, Systematics, Tetra.

\section{Introduction}

The genus Tyttobrycon Géry includes four miniature characid species (sensu Weitzman \& Vari, 1988) from the Amazon basin: T. dorsimaculatus Géry, T. hamatus Géry, T. spinosus Géry, and T. xeruini Géry. These species are characterized by a suite of apparently paedomorphic features, such as number of infraorbitals reduced, few or none perforated lateral line scales, and number of fin rays reduced, and also by the presence of some secondary sexual specializations such as bony hooks on fins and developed procurrent caudal-fin rays, as in T. spinosus (Géry, 1973). The genus Tyttobrycon was included in the Aphyoditeina group by Géry $(1973,1977)$. Since Lima et al. (2003) only considered monophyletic assemblages in grouping characid supra-specific taxa, Tyttobrycon was listed as incertae sedis in Characidae. Mirande's phylogenetic analysis of the Characidae (2010) recovered a monophyletic assemblage in the family composed by some of the genera of the "Aphyoditeina group", the subfamily Aphyoditeinae. The author did not include the genus Tyttobrycon in the analysis but hypothesized it would belong to this subfamily.
During a recent expedition to Marajó Island, Pará, Brazil, a new small characid species was discovered. The new species share most of the characters proposed by Géry (1973) for the genus Tyttobrycon and closely resembles T. dorsimaculatus, described from the rio Mamoré, a tributary of the rio Madeira basin. The aim of the present contribution is to formally describe the new species based on its unique combination of morphological features.

\section{Material and Methods}

Counts and measurements follow Fink \& Weitzman (1974), with the addition of head depth, measured at vertical through tip of supraoccipital spine. Horizontal scale rows below lateral line were counted to pelvic-fin insertion. Each count recorded in the description is followed by its occurrence in parentheses; asterisks indicate counts of the holotype. All measurements other than standard length (SL) are expressed as percents of SL, except subunits of the head, recorded as percents of head length. Supraneurals, gill-rakers on first gill arch, teeth, unbranched anal-fin rays, fin hooks, vertebrae, and procurrent caudal-fin rays were counted, and teeth morphology

${ }^{1}$ Museu de Zoologia da Universidade de São Paulo, Caixa Postal 42494, 04299-970 São Paulo, SP, Brazil.

(MMFM) manumfm@yahoo.com.br; (NAM) naercio@usp.br

${ }^{2}$ Programa de Pós-Graduação em Biologia de Água Doce e Pesca Interior, Instituto Nacional de Pesquisas da Amazônia, Caixa Postal 478, 69060, Manaus, AM, Brazil. avizdoug@gmail.com 
observed, in cleared and stained (c\&s) specimens, prepared according to Taylor \& Van Dyke (1985). Vertebrae of the Weberian apparatus were counted as four elements and the fused PU1+U1 of the caudal region as a single element. Precaudal vertebrae and caudal vertebrae definitions follows Weitzman (1962).

Each lot examined is preceded by catalog number, followed by the number of specimens in alcohol and SL range, the number and SL range of specimens measured and counted in parenthesis, and if any, the number of c\&s specimens, or number of specimens directly preserved in alcohol, without fixation in formalin (mol). Institutional abbreviations are ANSP, Academy of Natural Sciences of Drexel University, Philadelphia; DZSJRP, Departamento de Zoologia e Botânica da Universidade Estadual Paulista "Júlio de Mesquita Filho", São José do Rio Preto; INPA, Instituto Nacional de Pesquisas da Amazônia, Manaus; MCP, Museu de Ciências e Tecnologia, Pontifícia Universidade Católica do Rio Grande do Sul, Porto Alegre; MNRJ, Museu Nacional, Rio de Janeiro; MPEG, Museu Paraense Emílio Goeldi, Belém; MZUSP, Museu de Zoologia da Universidade de São Paulo, São Paulo.

\section{Results}

\section{Tyttobrycon marajoara, new species}

Figs. 1-2

Holotype. MZUSP 109196, 17.9 mm SL, male, Brazil, Pará State, Marajó Island, Salvaterra, Vila União, igarapé Olho d'água, 050'51'S 4834'1”W, 10 Apr 2010, M. M. F. Marinho \& D. A. Bastos.

Paratypes. Brazil. Pará State, Marajó Island. ANSP 193488, 4, 17.5-19.2 mm SL; DZSJRP 18179, 4, 16.8-18.6 mm SL; INPA 39504 4, 18.2-20.4 mm SL; MCP 47859, 4, 17.2-19.9 mm SL; MPEG 27051, 4, 17.5-19.5; MZUSP 106110, 68, 16.8-19.7 mm SL (19, 16.8-19.7 mm SL), 6 c\&s, 1 mol, igarapé in the balneário Olho no Olho, 051'53'S 48³4'16”'W, 10 Apr 2010, M. M. F. Marinho \& D. A. Bastos. MZUSP 108820, 24, 17.3-22.1 mm SL (15, 17.3-21.1 mm SL), collected with holotype. MZUSP 109197, 21, 9.9-12.3 mm SL, balneário Olho no Olho in igarapé, 051'53”S 48³4'16”W, 23 Aug 2010, D. A. Bastos.

Diagnosis. Tyttobrycon marajoara can be readily distinguished from all congeners by having tricuspid premaxillary teeth, tri- or pentacuspid maxillary teeth and four broad tricuspid anterior

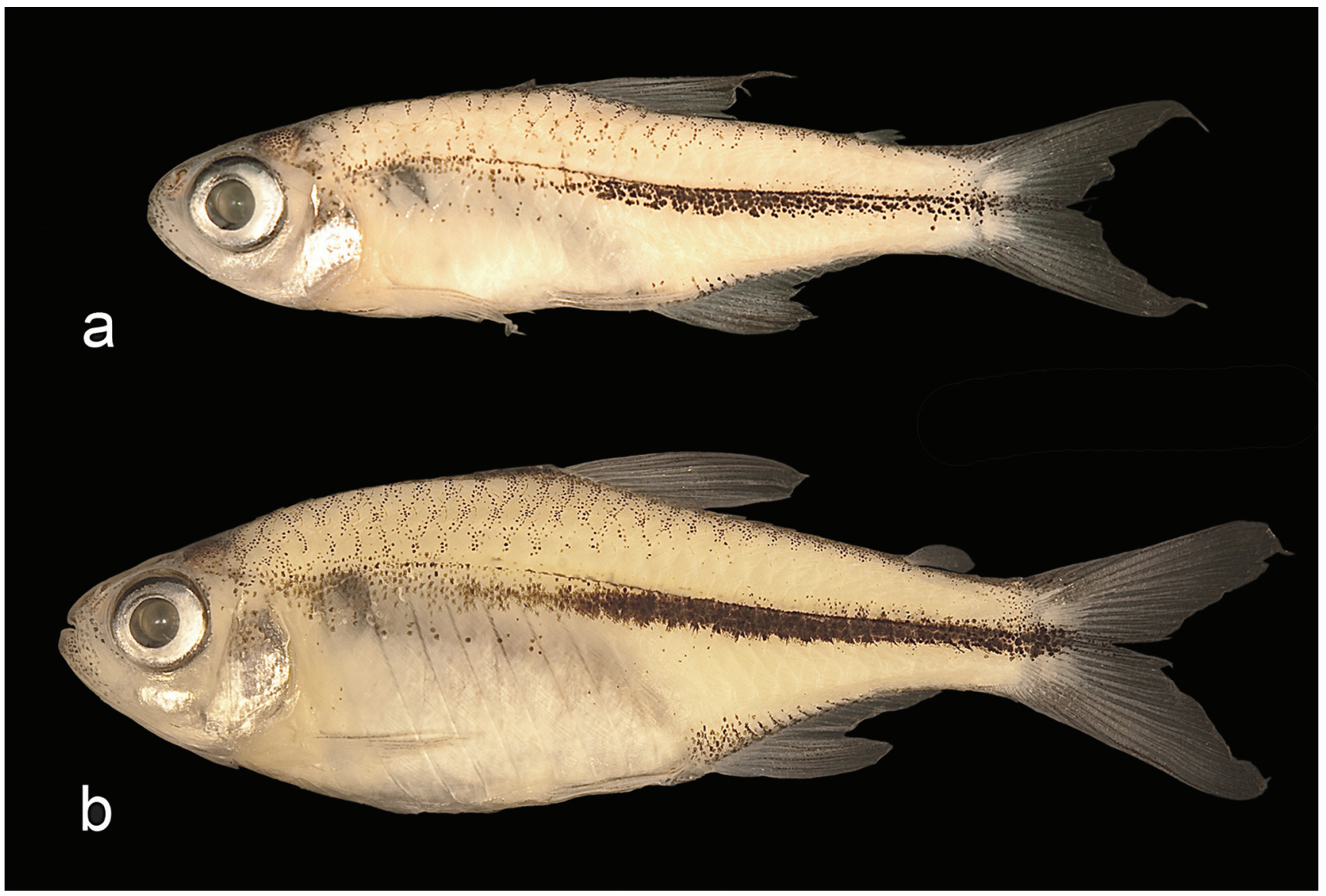

Fig. 1. Tyttobrycon marajoara: (a) Holotype, MZUSP 109196, 17.9 mm SL, mature male, igarapé Olho d'água, Vila União, Salvaterra, Pará, Brazil; (b) Paratype, MZUSP 108820, 20.9 mm SL, mature female, collected with holotype. 


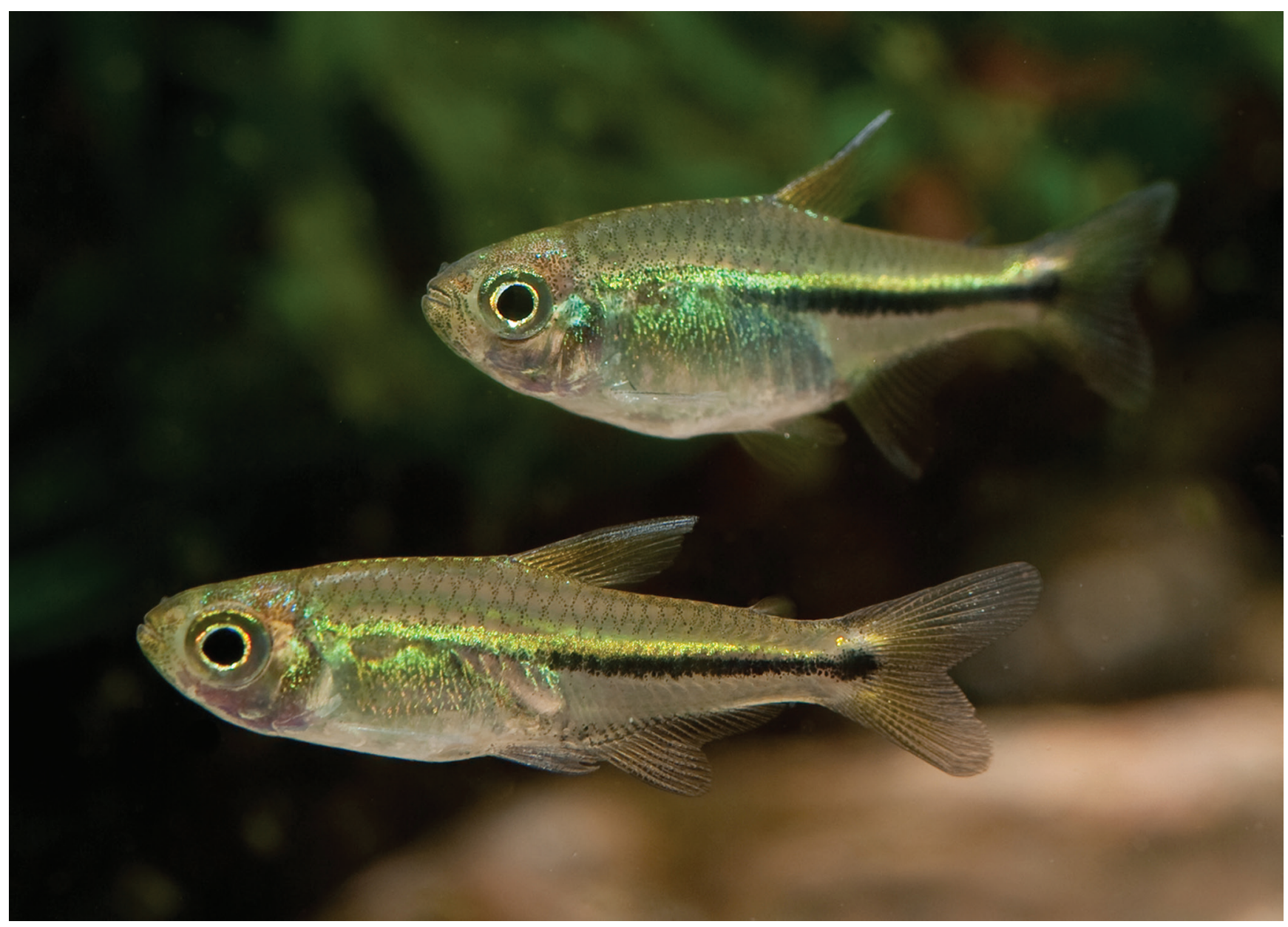

Fig. 2. Tyttobrycon marajoara alive. Female above, male below, collected with paratypes in a small stream (igarapé) at balneário Olho no Olho, Marajó Island, Pará State, Brazil. Not preserved.

dentary teeth ( $v s$. all teeth conical in the jaws). Additionally, it can be distinguished from all congeners, except $T$. dorsimaculatus, by having 5-7 premaxillary teeth (vs. 8-9), and from T. dorsimaculatus by having only scattered melanophores on the dorsal fin ( $v s$. dorsal fin with a conspicuous black spot). Furthermore, Tyttobrycon marajoara can be distinguished from T. hamatus and T. spinosus by having an adipose fin (vs. adipose fin absent).

Description. Morphometrics in Table 1. Largest specimen examined $21.1 \mathrm{~mm}$ SL. Body compressed, greatest body depth slightly anterior to dorsal-fin origin. Dorsal body profile convex from tip of snout to nostrils; straight from nostrils to tip of supraoccipital spine, slightly depressed at fontanels; almost straight from supraoccipital spine to dorsal-fin origin on males, convex on females; posteroventrally inclined along dorsal-fin base; slightly convex from base of last dorsal-fin ray to adipose fin; straight along caudal peduncle. Ventral body profile convex from tip of lower jaw to vertical through pectoral-fin origin; straight from pectoral-fin origin to pelvicfin origin on males, convex on females; slightly concave from pectoral-fin origin to anal-fin origin on males, straight on females; posterodorsally inclined along anal-fin base; straight along caudal peduncle.

Mouth upturned. Premaxillary with 5(2), 6(4), or 7(1) tricuspid teeth, in a regular row; some specimens with third tooth slightly ahead from remaining. Maxilla with 1(6) or 2(1) tri- or pentacuspid teeth, posterior tip beyond vertical through anterior border of orbit. Dentary with four broad tricuspid teeth anteriorly; one male and one female with largest teeth pentacuspidate; 3(1) or 4(6) smaller teeth tricuspid or conical, laterally located (Fig. 3). Infraorbital bones reduced in number: infraorbital four, five and six absent.

Pseudotympanum large, muscle hiatus anterior to first pleural rib and between first and second pleural ribs, dorsally limited by lateralis superficialis muscle. The anterior hiatus is limited anteroventrally by obliquus superioris and posteriorly by first pleural rib. Posterior hiatus limited anteroventrally by obliquus superioris and posteriorly by second pleural rib (Fig. 4).

Supraneurals 3(2) or 4(5), I-shaped. Dorsal-fin rays ii,8(1) or $9 *(36)$; first unbranched ray almost one-half length of second unbranched ray. Tiny spines laterally positioned on 


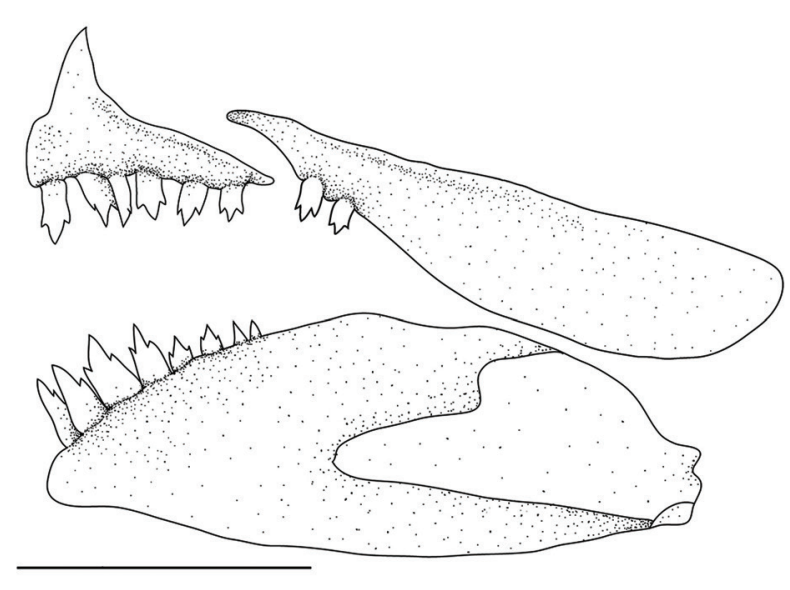

Fig. 3. Jaws of Tyttobrycon marajoara, paratype, MZUSP 106110, $20.5 \mathrm{~mm}$ SL. Scale bar $=1 \mathrm{~mm}$, left side.

last unbranched dorsal-fin ray of males (Fig. 5). Adiposefin origin slightly posterior to vertical through anal-fin base end. Pectoral-fin rays i,8(4), 9(6), or 10*(26), its tip reaching pelvic-fin origin. Pelvic-fin rays i,7*. Pelvic-fin origin slightly anterior to vertical through dorsal-fin origin; tip of pelvic fin extending to bases of first three branched anal-fin rays in adult males, and first two unbranched anal-fin rays, or not reaching anal fin, in adult females (Fig. 1). Bony hooks on all pelvicfin rays of males (Fig. 6). Anal-fin rays iii(3) or iv(3), 12(3), $13(10)$, or $14 *(18)$. Anal-fin origin slightly posterior to vertical through base of last dorsal-fin ray. Last unbranched anal-fin ray and first four or five branched anal-fin rays longer than remaining rays. Bony hooks on last unbranched and first five or six branched anal-fin rays of males (Fig. 7). Caudal-fin forked,

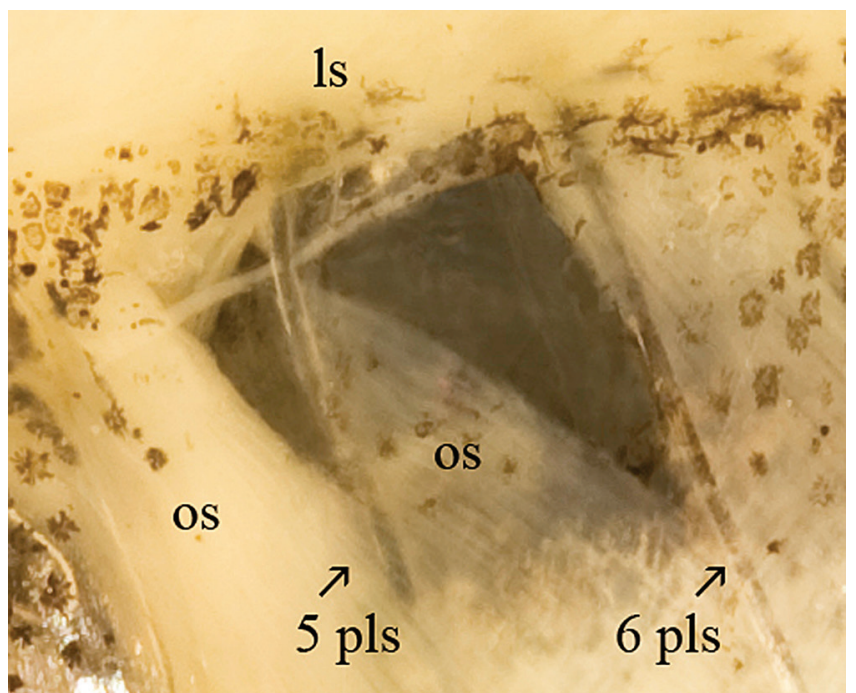

Fig. 4. External view of muscle covering the anterior portion of the swim bladder of Tyttobrycon marajoara, paratype, MZUSP 106110, $19.6 \mathrm{~mm} \mathrm{SL}$, mature female. Skin and adipose tissue removed, left side. $5 \mathrm{plr}=$ fifth pleural rib; $6 \mathrm{plr}=$ sixth pleural rib; ls = lateralis superficialis; os = obliquus superioris . both lobes about equally developed. Principal caudal-fin rays i, $9,8, i^{*}$. Scales on caudal fin restricted to base of fin. Dorsal procurrent rays $8(2), 9(3)$, or 10(1), and ventral procurrent rays $6(1), 7(2)$, or $8(3)$.

Table 1. Morphometrics of Tyttobrycon marajoara, $\mathrm{n}=$ number of specimens; $\mathrm{SD}=$ Standard Deviation.

\begin{tabular}{|c|c|c|c|c|c|}
\hline & \multicolumn{5}{|c|}{ Paratypes } \\
\hline & Holotype & $\mathrm{n}$ & range & Mean & $\mathrm{SD}$ \\
\hline Standard length & 17.9 & 31 & $15.6-21.1$ & 18.6 & - \\
\hline \multicolumn{6}{|c|}{ Percentages of standard length } \\
\hline \multicolumn{6}{|l|}{$\begin{array}{l}\text { Depth at dorsal-fin } \\
\text { origin }\end{array}$} \\
\hline Males & 27.9 & 14 & $25.4-29.4$ & 27.4 & 1.3 \\
\hline Females & - & 17 & $29.1-36.1$ & 32.2 & 1.8 \\
\hline $\begin{array}{l}\text { Snout to dorsal-fin } \\
\text { origin }\end{array}$ & 50.0 & 31 & $49.6-54.6$ & 52.3 & 1.4 \\
\hline $\begin{array}{l}\text { Snout to } \\
\text { pectoral-fin origin }\end{array}$ & 29.4 & 31 & $26.7-32.2$ & 29.2 & 1.2 \\
\hline $\begin{array}{l}\text { Snout to pelvic-fin } \\
\text { origin }\end{array}$ & 48.9 & 31 & $48.0-55.7$ & 50.9 & 1.7 \\
\hline $\begin{array}{l}\text { Snout to anal-fin } \\
\text { origin }\end{array}$ & 63.4 & 31 & $62.5-69.4$ & 65.2 & 1.9 \\
\hline $\begin{array}{l}\text { Caudal-peduncle } \\
\text { depth }\end{array}$ & 12.3 & 31 & $9.1-13.0$ & 11.3 & 0.9 \\
\hline $\begin{array}{l}\text { Caudal-peduncle } \\
\text { length }\end{array}$ & 15.3 & 31 & $12.4-17.4$ & 15.0 & 1.3 \\
\hline \multicolumn{6}{|l|}{ Pectoral-fin length } \\
\hline Males & 20.7 & 14 & $18.1-23.6$ & 21.0 & 1.5 \\
\hline Females & - & 17 & $16.5-21.0$ & 18.6 & 1.4 \\
\hline \multicolumn{6}{|l|}{ Pelvic-fin length } \\
\hline Males & 19.5 & 14 & $17.8-20.4$ & 19.4 & 0.7 \\
\hline Females & - & 17 & $14.4-17.9$ & 16.4 & 0.9 \\
\hline $\begin{array}{l}\text { Pelvic-fin origin to } \\
\text { anal-fin origin }\end{array}$ & 14.2 & 35 & 12.018 .8 & 15.0 & 1.8 \\
\hline Dorsal-fin length & 27.9 & 31 & $24.1-29.8$ & 26.9 & 1.8 \\
\hline $\begin{array}{l}\text { Dorsal-fin base } \\
\text { length }\end{array}$ & 12.2 & 31 & $10.5-15.4$ & 13.0 & 1.0 \\
\hline Anal-fin length & 18.6 & 31 & $17.5-22.4$ & 19.8 & 1.5 \\
\hline $\begin{array}{l}\text { Anal-fin base } \\
\text { length }\end{array}$ & 22.6 & 31 & $18.1-25.6$ & 22.0 & 1.7 \\
\hline $\begin{array}{l}\text { Eye to } \\
\text { dorsal-fin origin }\end{array}$ & 37.7 & 31 & $35.3-41.3$ & 38.9 & 1.3 \\
\hline $\begin{array}{l}\text { Dorsal-fin origin to } \\
\text { caudal-fin base }\end{array}$ & 50.0 & 31 & $50.0-56.3$ & 52.5 & 1.5 \\
\hline Head depth & 23.2 & 31 & $22.0-28.5$ & 24.8 & 1.5 \\
\hline Head length & 30.7 & 31 & $27.1-32.0$ & 29.4 & 1.5 \\
\hline \multicolumn{6}{|c|}{ Percentages of head length } \\
\hline $\begin{array}{l}\text { Horizontal eye } \\
\text { diameter }\end{array}$ & 41.2 & 31 & $35.9-46.6$ & 41.1 & 2.6 \\
\hline Snout length & 21.7 & 31 & $17.2-24.1$ & 20.5 & 1.5 \\
\hline Interorbital width & 28.6 & 31 & $24.3-31.0$ & 28.5 & 1.6 \\
\hline Upper jaw length & 33.3 & 31 & $28.5-40.1$ & 33.6 & 2.5 \\
\hline
\end{tabular}




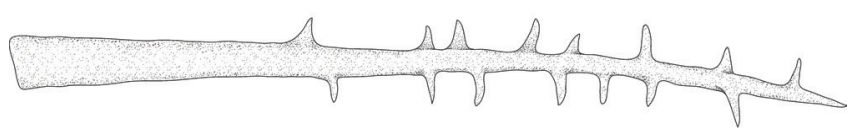

Fig. 5. Bony spines on the first dorsal fin-ray of a male of Tyttobrycon marajoara, paratype, MZUSP 106110, $18.9 \mathrm{~mm}$ SL. Dorsal view.

Scales cycloid. Lateral line incomplete, pored scales 3(1), $4(11)$, or $5 *(17)$. Longitudinal scale row, including pored scales 28(4), 29(8), 30*(10), or 31(4). Predorsal scales $9 *(8)$, 10(20), or 11(1). Longitudinal scale rows above lateral line $4^{* *}$; longitudinal scale rows below lateral line at pelvicfin origin $3^{* *}$. Single row of 1-3 scales overlying base of anteriormost anal-fin rays. Scales around caudal peduncle $12 * *$. Axillary scale present.

Precaudal vertebrae 13 (1), 14 (6), caudal vertebrae 17 (1), 18 (5), or 19 (1). Total vertebrae 31(2), 32(4), or 33(1). First gill arch with 1(1) or 2(5) hypobranchial, 1(5) on cartilage between hypobranchial and ceratobranchial, 8(1) or 9(5) ceratobranchial, 1(6) on cartilage between ceratobranchial and epibranchial, and 6(2) or 7(4) epibranchial gill-rakers. Four branchiostegal rays: three located on anterior ceratohyal and one on posterior ceratohyal.

Color in alcohol. Overall ground coloration pale. Dorsal portion of head and upper and lower lips with dense concentration of melanophores. First and second infraorbitals, maxilla and dorsal portion of opercle with scattered dark cromatophores. Infraorbital, opercular and gular areas silvery. Dorsal portion of body with scales bordered by melanophores; predorsal area with dark brown stripe. Humeral spot absent. Scattered melanophores from opercle to near vertical through dorsal-fin origin, united to a conspicuous longitudinal black stripe from later point to base of middle caudal-fin rays. Series of oblique and parallel black lines at anal-fin base. Middle caudal-fin rays dark, as an extension of the longitudinal black stripe; caudal-fin lobes with scattered melanophores. Scattered melanophores on distal margins of first seven dorsal-fin rays; on distal margins of largest unbranched and first six anal-fin rays; on first three or four pectoral-fin rays; and on fist four pelvic-fin rays.

Color in life. Dorsolateral portion of body from head to base of caudal fin translucent. Iridescent yellow to green stripe, from opercle to base of caudal fin; black stripe below it, from vertical through dorsal-fin origin to base of middle caudal-fin rays. Iridescent pigmentation yellow to green over posterodorsal region of head, opercle areas and upper lateral portions of abdominal region. Ventrolateral portion of body from anal-fin origin to base of caudal fin translucent. All fins hyaline, except for a yellowish area at base of dorsal and caudal fin, and a white area on the distal portion of the anterior dorsal-fin rays (Fig. 2).

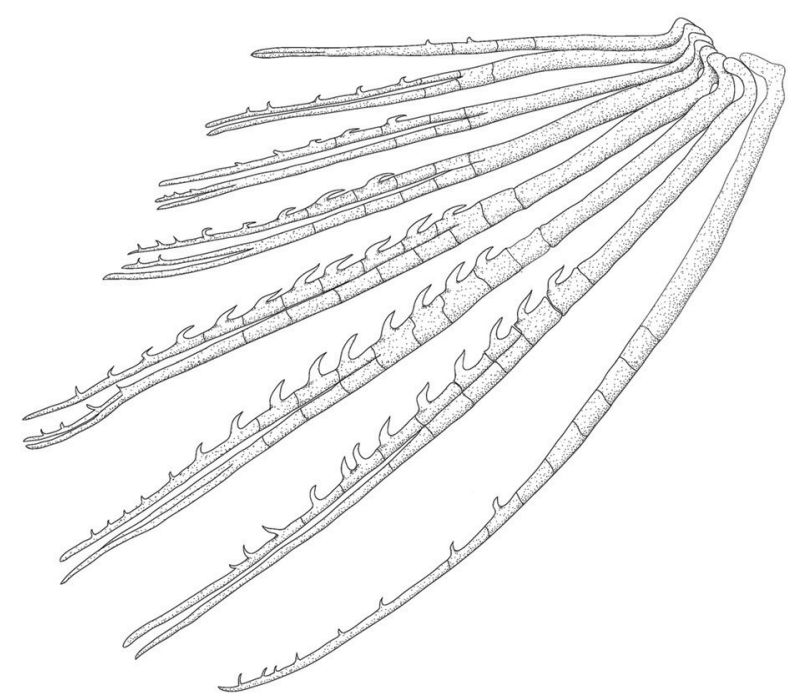

Fig. 6. Bony hooks on pelvic fin of a male of Tyttobrycon marajoara, paratype, MZUSP 106110, $18.9 \mathrm{~mm}$ SL. Ventral view, left side.

Sexual dimorphism. Spines and hooks on fins present only in males (Figs. 5-7). Tiny spines laterally located on unbranched dorsal-fin rays; hooks on all pelvic-fin rays and on last unbranched and first five or six branched anal-fin rays. Males with shallower body depth and longer pectoral and pelvic fins than females (Fig. 8). Medial portion of pelvic bone of males expanded and dorsally projected (Fig. 9).

Distribution. Tyttobrycon marajoara is known from two small streams located on the east portion of Marajó Island (Fig. 10).

Ecological notes. The two sampled streams are temporary, drying completely during the dry season, from September to February, and flowing on the rainy season, from March to August (Fig. 11). Specimens of Tyttobrycon marajoara were

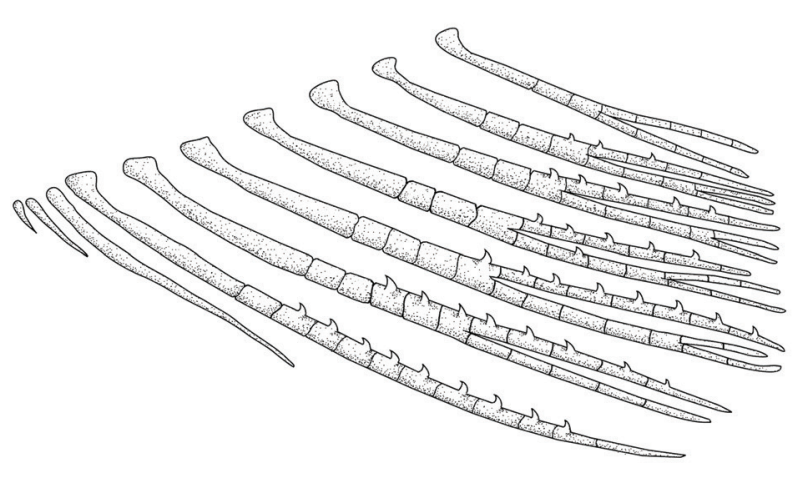

Fig. 7. First anal-fin rays of a male of Tyttobrycon marajoara, paratype, MZUSP 106110, $18.9 \mathrm{~mm} \mathrm{SL}$, with bony hooks. Lateral view, left side. 


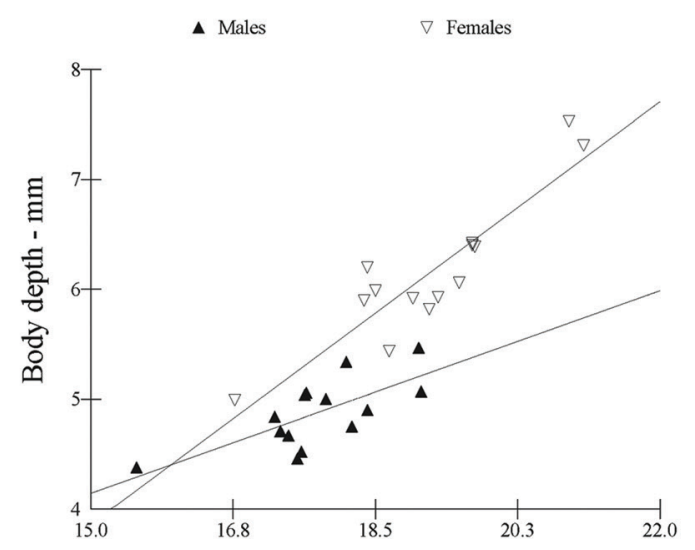

a

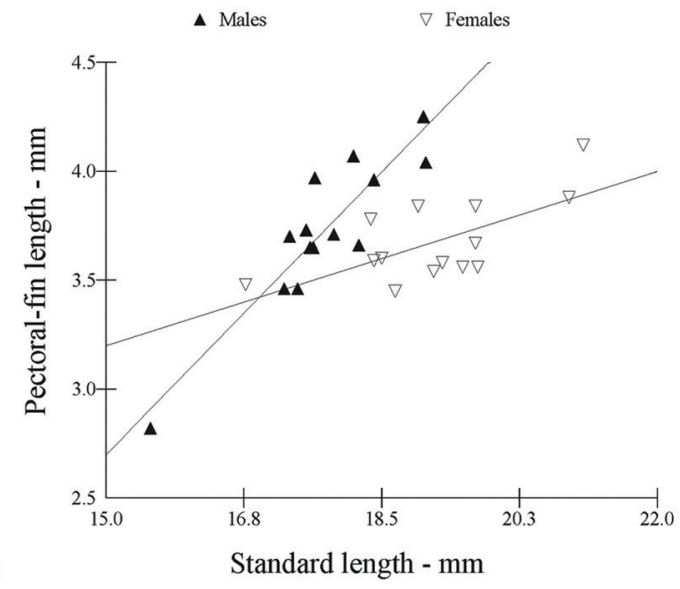

b

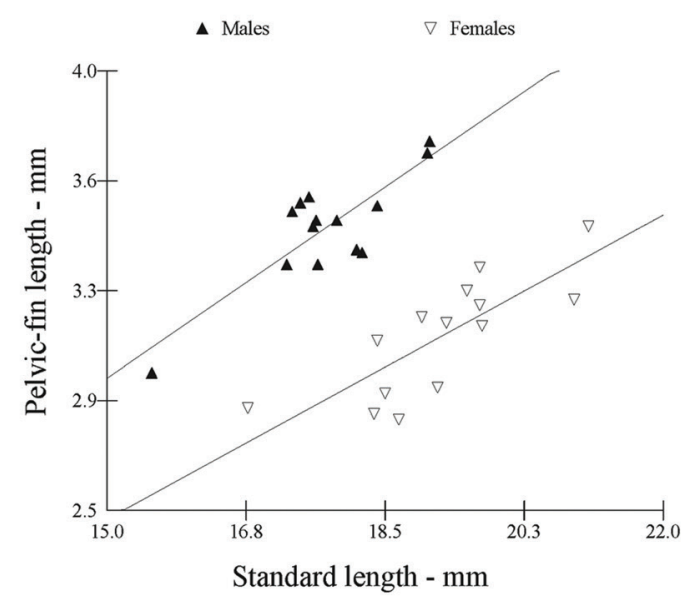

Fig. 8. Fin lengths and body depth as a function of standard length by sex for Tyttobrycon marajoara: (a) body depth, (b) pectoral fin, (c) pelvic fin.

observed (during snorkeling) and/or captured in April and August of 2010, at the rainy season. In April, small groups of 10 to 15 adult specimens were observed and captured on a

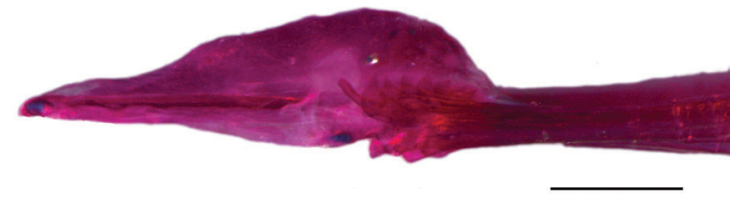

b

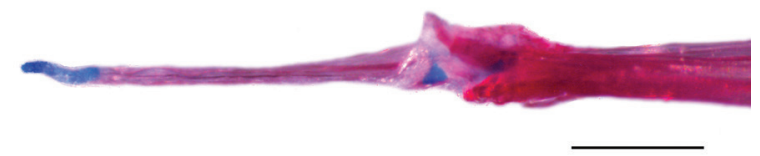

Fig. 9. Lateral view of left pelvic bone of male (a) and anterior portion of pelvic-fin rays of female (b) of Tyttobrycon marajoara, paratype, MZUSP 106110.

the bottom and marginal portions of the streams. In August, large schools of juveniles were observed and captured along the bottom of the stream.

Species collected with Tyttobrycon marajoara were Aequidens tetramerus (Heckel), Apistogramma agassizii (Steindachner), Acaronia nassa (Heckel), Bryconops melanurus (Bloch), Copella arnoldi (Regan), Crenuchus spilurus Günther, Curimatopsis crypticus Vari, Hemigrammus levis Durbin, Hemigrammus ocellifer (Steindachner), Hemigrammus rhodostomus Ahl, Hemigrammus rodwayi Durbin, Hoplerythrinus unitaeniatus (Spix \& Agassiz), Hoplias malabaricus (Bloch), Hyphessobrycon heterorhabdus (Ulrey), Megalechis sp., Microcharacidium weitzmani Buckup, Moenkhausia collettii (Steindachner), Nannostomus eques Steindachner, Nannostomus nitidus Weitzman, Pyrrhulina sp. and Rivulus sp.

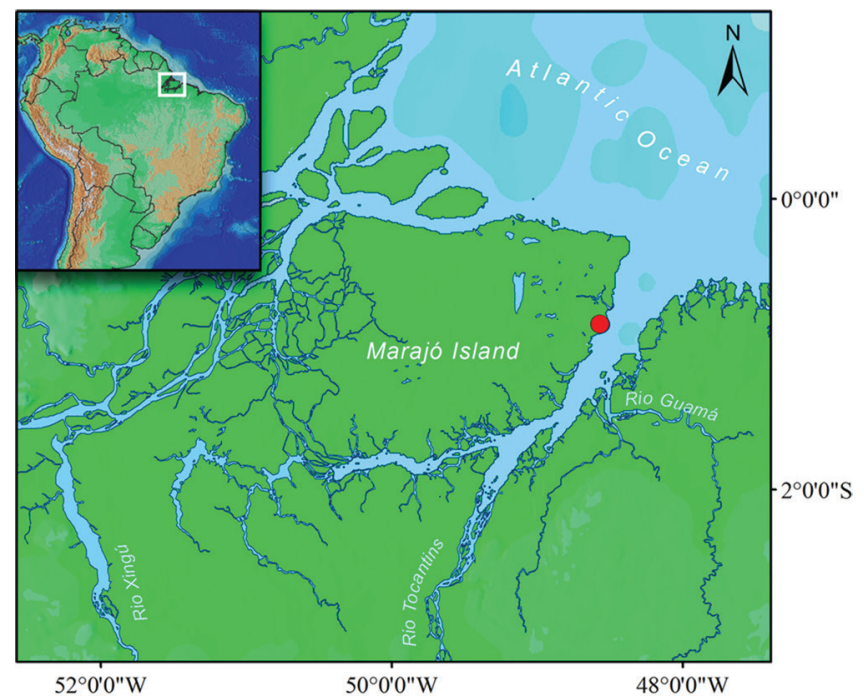

Fig. 10. Distribution of Tyttobrycon marajoara on the east portion of Marajó Island, Pará State, Brazil. Red dot represents two localities. 

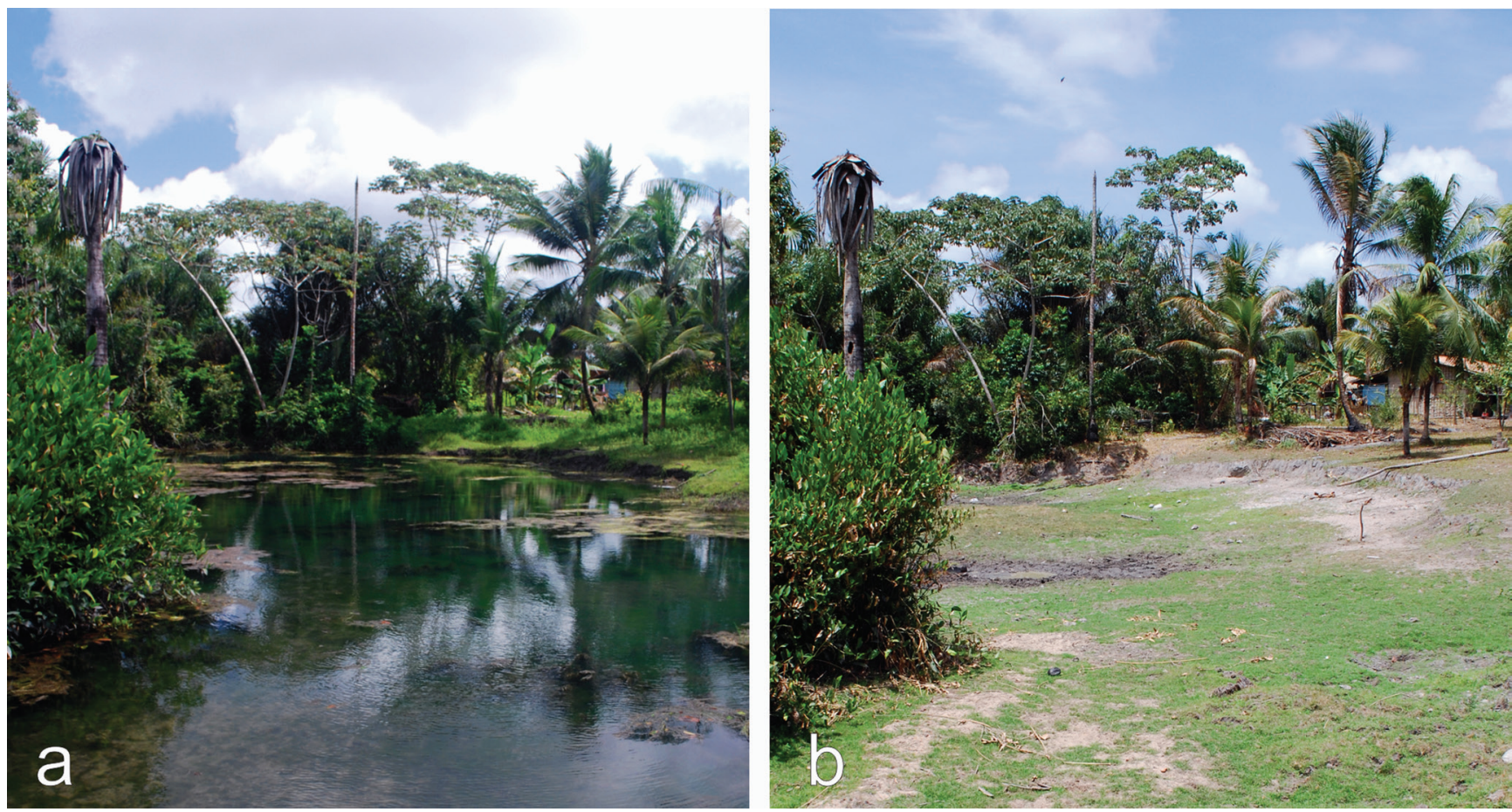

Fig. 11. Type locality of Tyttobrycon marajoara, Igarapé Olho d'água: (a) wet season at June, 2009; (b) dry season at October, 2009.

Etymology. The specific name, marajoara, refers to the type locality, Marajó Island, Brazil. An adjective.

\section{Discussion}

In a weighted parsimony phylogenetic analysis of Characidae, Mirande (2010) attempted to better define Géry's $(1973,1977)$ Aphyoditeina group. The genus Tyttobrycon was not examined, but was provisionally considered as belonging to Aphyoditeinae. At this point we think that any effort to reconstruct relationships of our new species within the Characidae would require a thorough phylogenetic analysis, which is beyond the scope of this work. We prefer to consider it as belonging to Tyttobrycon, until a detailed investigation of its phylogenetic relationships can be conducted.

Géry's definition of Tyttobrycon is based on a combination of more than ten morphological characters, also found in other small characids, such as premaxilla bearing less than ten conical teeth in a single, more or less regular series, dentary with ten or less conical teeth in a single series, number of infraorbitals reduced, lateral line very short or lacking, pseudotympanum present, anal-fin short, hooks present on anal fin of mature males, caudal fin not scaled (Géry, 1973). Tyttobrycon marajoara share all the features proposed by Géry for the genus, except the strictly presence of conical teeth. Nevertheless, Tyttobrycon is the genus of Characidae that best fits the new species.

Tyttobrycon marajoara and T. dorsimaculatus share certain morphological features not commonly found in other members of the Characidae. They have a similar color pattern consisting of a black longitudinal stripe represented by few scattered melanophores at the humeral region, becoming more conspicuous from near the vertical through dorsal-fin origin to the base of the middle caudal-fin rays, and a series of oblique and parallel black lines at the anal-fin base. Tyttobrycon dorsimaculatus, however, has a deep black mark on the first five dorsal-fin rays, whereas in T. marajoara only scattered melanophores are present on this area, which is white in life. Males of both species are characterized by similar sexually dimorphic features represented by tiny spines laterally located on the dorsal fin, bony hooks on pelvic and anal fins, relatively shallower bodies, longer pectoral and pelvic fins and the medial portion of the pelvic bone expanded and dorsally projected. Furthermore, both species have a very similar pseudotympanum, consisting of a muscle hiatus anterior to the fifth pleural rib and between the fifth and sixth pleural ribs.

Similar muscle gaps were described for Atopomesus pachyodus Myers, Axelrodia sp., Paracheirodon axelrodi (Schultz) (Malabarba, 1998), were found in Hyphessobrycon elachys Weitzman (personal observation), and used as synapomorphies to characterize Amazonspinther Bührnheim, Carvalho, Malabarba \& Weitzman, and Spintherobolus Weitzman \& Malabarba (Weitzman \& Malabarba, 1999; Bührnheim et al., 2008). Mattox \& Toledo-Piza (2012: character 10, state 0 ) described a similar pseudotympanum for members of Acanthocharax, Acestrocephalus, Charax, Cynapotamus, Galeocharax, Phenacogaster, Roeboides and Xenocharax, also discussed by Menezes (2006) for species of Acestrocephalus. However, in the Characinae, the hiatus 
anterior to the fifth pleural rib is very small when compared to the hiatus between the fifth and sixth pleural ribs, the pseudotympanum is only crossed by the fifth rib in lateral view (Menezes, 2006, fig. 5a, b, d, e, g; Mattox \& Toledo-Piza, 2012, fig. 2a, b, e). In Tyttobrycon dorsimaculatus, T. marajoara, Atopomesus pachyodus, Amazonspinther, Axelrodia sp., Hyphessobrycon elachys, Paracheirodon axelrodi, and Spintherobolus species, the anterior hiatus is large when compared to the posterior hiatus, the pseudotympanum is crossed by the fifth rib and the obliquus superioris, in a lateral view (Fig. 4; Weitzman \& Malabarba, 1999, fig. 4, 5, 6; Bührnheim et al., 2008, fig. 1). The pseudotympanum of Tyttobrycon xeruini, the type species of Tyttobrycon, is represented by a small hiatus only anterior to the fifth pleural rib (Mattox \& Toledo-Piza, 2012: character 10, state 1).

\section{Comparative material examined}

Amazonspinther dalmata. Brazil. Amazonas State. MZUSP 73606, 2, 13.7-14.3 mm SL, rio Madeira drainage. Atopomesus pachyodus. Brazil. Amazonas State: MZUSP 29612, 18, 17.3-28.3 mm SL, rio Negro drainage. Axelrodia lindae. Brazil. Amazonas State. MZUSP 109564, 2, 19.7-19.9 mm SL, rio Negro drainage. Hyphessobrycon elachys: Brazil. Mato Grosso State. MZUSP 96661, 6, 12.0-15.0 mm SL, rio Paraguay drainage. Paracheirodon axelrodi. Brazil. Amazonas State. MZUSP 109447, 145, 17.1-21.7 mm SL, rio Negro drainage. Tyttobrycon xeruini. Brazil. Amazonas State. MZUSP 17467, 1782, 12.2-17.7 mm SL, 2 c\&s, rio Solimões drainage; MZUSP 29604, 13, 16.1-19.5 mm SL, 2 c\&s, rio Negro drainage. Spintherobolus ankoseion. Brazil. Santa Catarina State. MZUSP 51024, 11 paratypes, 22.4-26.2 mm SL, Coastal drainages. Spintherobolus leptoura. Brazil. São Paulo State. MZUSP 51023, 9 paratypes, 16.4-27.5 mm SL, rio Ribeira de Iguape drainage. Tyttobrycon dorsimaculatus. Peru. Madre de Dios State. MZUSP 89943, 41, 16.3-19.5 mm SL, 3 c\&s, Madre de Dios drainage.

\section{Acknowledgments}

We are grateful to Fernando Carvalho (UNESP/IBILCE) for reading and commenting the manuscript. Ricardo Kawada (MZUSP) for taking pictures for figures 5-7. FAPESP for financial support MMFM: (2009/15075-0) and South American Characiformes Inventory (FAPESP 2011/50282-7, http://www.usp.br/peixes).

\section{Literature Cited}

Bürnheim, C. M., T. P. Carvalho, L. R. Malabarba \& S. H. Weitzman. 2008. A new genus and species of characid from the Amazon basin - the recognition of a relictual lineage of characid fishes (Ostariophysi: Cheirodontinae: Cheirodontini). Neotropical Ichthyology, 6: 663-678.
Fink, W. L. \& S. H. Weitzman. 1974. The so-called Cheirodontin fishes of Central America with description of two new species (Pisces, Characidae). Smithsonian Contributions to Zoology, 172: 1-46.

Géry, J. 1973. New and little-known Aphyoditeina (Pisces, Characoidei) from the Amazon basin. Studies on Neotropical Fauna, 8: 81-137.

Géry, J. 1977. Characoids of the World. Neptune City, TFH Publications.

Lima, F. C. T., L. R. Malabarba, P. A. Buckup, J. F. P. Silva, R. P. Vari, A. Harold, R. C. Benine, O. Oyakawa, C. S. Pavanelli, N. A. Menezes, C. A. S. Lucena, M. C. S. L. Malabarba, Z. M. S. Lucena, R. E. Reis, F. Langeani, L. Casatti, V. A. Bertaco, C. Moreira \& P. H. F. Lucinda. 2003. Genera incertae sedis in Characidae. Pp. 106-169. In: Reis, R. E., S. O. Kullander \& C. J. Ferraris Jr (Eds.). Check List of the Freshwater Fishes of South and Central America. Porto Alegre, Edipucrs.

Malabarba, L. R. 1998. Monophyly of the Cheirodontinae, characters and major clades (Ostariophysi, Characidae). Pp. 193-234. In: Malabarba, L. R., R. E. Reis, R. P. Vari, Z. M. S. Lucena \& C. A. S. Lucena (Eds.). Phylogeny and classification of Neotropical fishes, Edipucrs, Porto Alegre.

Mattox, G. M. T. \& M. Toledo-Piza. Phylogenetic study of the Characinae (Teleostei: Characiformes: Characidae). Zoological Journal of the Linnean Society, 165: 809-915.

Menezes, N. A. 2006. Description of five new species of Acestrocephalus Eigenmann and redescription of $A$. sardina and $A$. boehlkei (Characiformes: Characidae). Neotropical Ichthyology 4: 385-400.

Mirande, J. M. 2010. Phylogeny of the family Characidae (Teleostei: Characiformes): from characters to taxonomy. Neotropical Ichthyology, 8: 385-568.

Taylor, W. R. \& G. C. Van Dyke. 1985. Revised procedures for staining and clearing small fishes and other vertebrates for bone and cartilage study. Cybium, 9: 107-119.

Weitzman, S. H. 1962. The osteology of Brycon meeki, a generalized characid fish, with an osteological definition of the family. Stanford Ichthyological Bulletin, 8: 1-77.

Weitzman, S. H. \& L. R. Malabarba, 1999. Systematics of Spintherobolus (Teleostei: Characidae: Cheirodontinae) from Eastern Brazil. Ichthyological Exploration of Freshwaters, 10: 1-43.

Weitzman, S. H. \& R. P. Vari. 1988. Miniaturization in South American freshwater fishes; an overview and discussion. Proceedings of the Biological Society of Washington, 101: 444-465.

Submitted April 22, 2013

Accepted August 5, 2013 by George Mattox Published December 27, 2013 